\title{
A recent reconnaissance of the central Helmand Valley
}

\author{
Marc A. Abramiuk*
}

\section{Introduction}

Archaeological fieldwork in the central Helmand Valley of modern-day Afghanistan has been sparse as a result of the region's remoteness and lack of security; the work that has been done suggests that the area has been occupied since prehistoric times. The Central Helmand Archaeological Study (CHAS) is the most recent archaeological field research to be conducted in the valley. It was launched in 2011 with the support of the US Marine Corps and the Government of the Islamic Republic of Afghanistan, to locate and record archaeological sites in the region and to report any evidence of looting or damage (Abramiuk $\&$ Wong 2015). This paper reports on some early findings in the course of continuing analysis and provides a preliminary assessment.

\section{Background}

The Helmand River, with its headwaters in the Hindu Kush Mountains of north-eastern Afghanistan and its dissipation in the Seistan marshlands at the border of Afghanistan and Iran (Figure 1), is the longest permanent river situated between and within the same latitudinal zone as the Indus and the Tigris. It offers some of the most fertile river valley land for settled life in southern Central Asia. Based mainly on excavated finds at Mundigak, Deh Morasi Ghundai and Said Qala Tepe near Kandahar (Allchin \& Hammond 1978), and Shahr-i-Sokhta in eastern Iran (Tosi 1968), Jim Shaffer (1992: 459) recognises a Helmand Tradition dating back to $4000 \mathrm{BC}$. His work indicates that the central Helmand waterway between these two localities was important to people from the earliest of times.

The last and most significant published archaeological research on the central valley is that of Norman Hammond's 1966 reconnaissance from Qala-i-Bost, at the confluence of the Helmand and Arghandab, downstream to Rudbar (Hammond 1970). It identified evidence of occupation from the Achaemenid period (sixth to fourth centuries BC) onward, with the preponderance of ceramic evidence coming from the Islamic period (mainly between the tenth and thirteenth centuries AD), and to a lesser extent from the late Kushan and Sassanian periods (third to seventh centuries AD). Only one ceramic sherd collected by Hammond in the central Helmand Valley was inferred to be of prehistoric date, thus hinting that the central Helmand Valley, akin to the upper valley and delta regions, may have been occupied during the Bronze Age or earlier.

* California State University Channel Islands, Department of Sociology and Anthropology, 1 University Drive, Camarillo, CA 93012,USA (Email: marc.abramiuk@csuci.edu) 


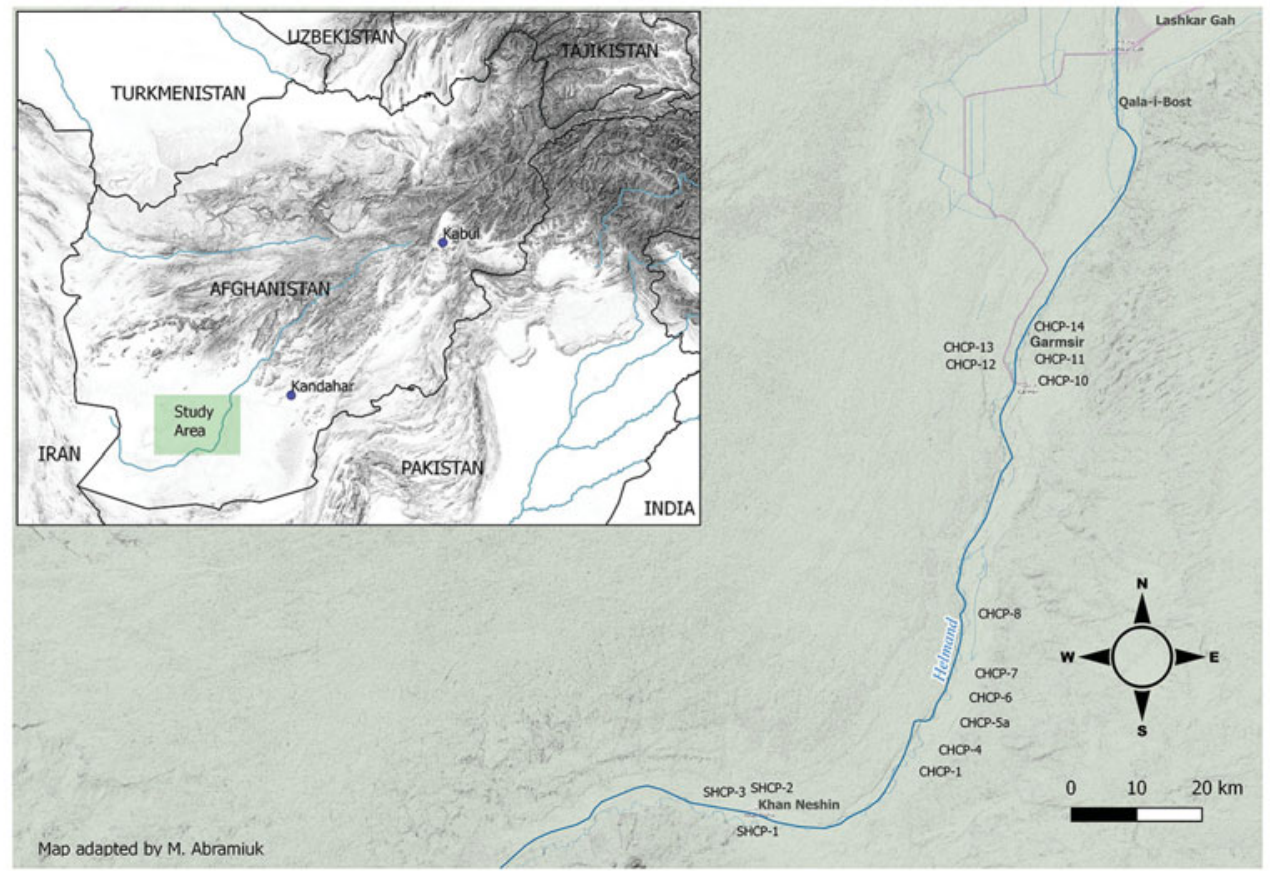

Figure 1. Study area in the central Helmand Valley, Afghanistan. The locations of the sites that were investigated are approximated and labelled with archaeological site designations devised by the author.

\section{Methods}

The CHAS investigated both banks of the Helmand River between Garmsir and Khan Neshin (Figure 1). Prospective archaeological sites were initially located by systematically inspecting satellite and aerial photographic imagery of the region, and by interviewing local nationals and US Marines who patrolled the area. A final list of potential archaeological sites was drawn up and the intensive survey phase of the study was initiated. With the logistical support of the marines, the prospective sites were ground-truthed. The verified archaeological sites were then photographed and the surface scatter examined for identifiable and datable artefacts. Diagnostic sherds were collected and photographed; they are currently housed at the Ministry of Information and Culture (MoIC) in Kabul.

\section{Results}

The CHAS recorded 11 archaeological sites in Garmsir District. One free-standing arched structure, a relatively intact building and a portion of another building appeared to be closely associated and were therefore designated as a single site. Future research may prove that they should be considered separate sites, but for the purposes of this study, they were aggregated. Three sites and what resembled the base of a column in a field were documented (C) Antiquity Publications Ltd, 2017 


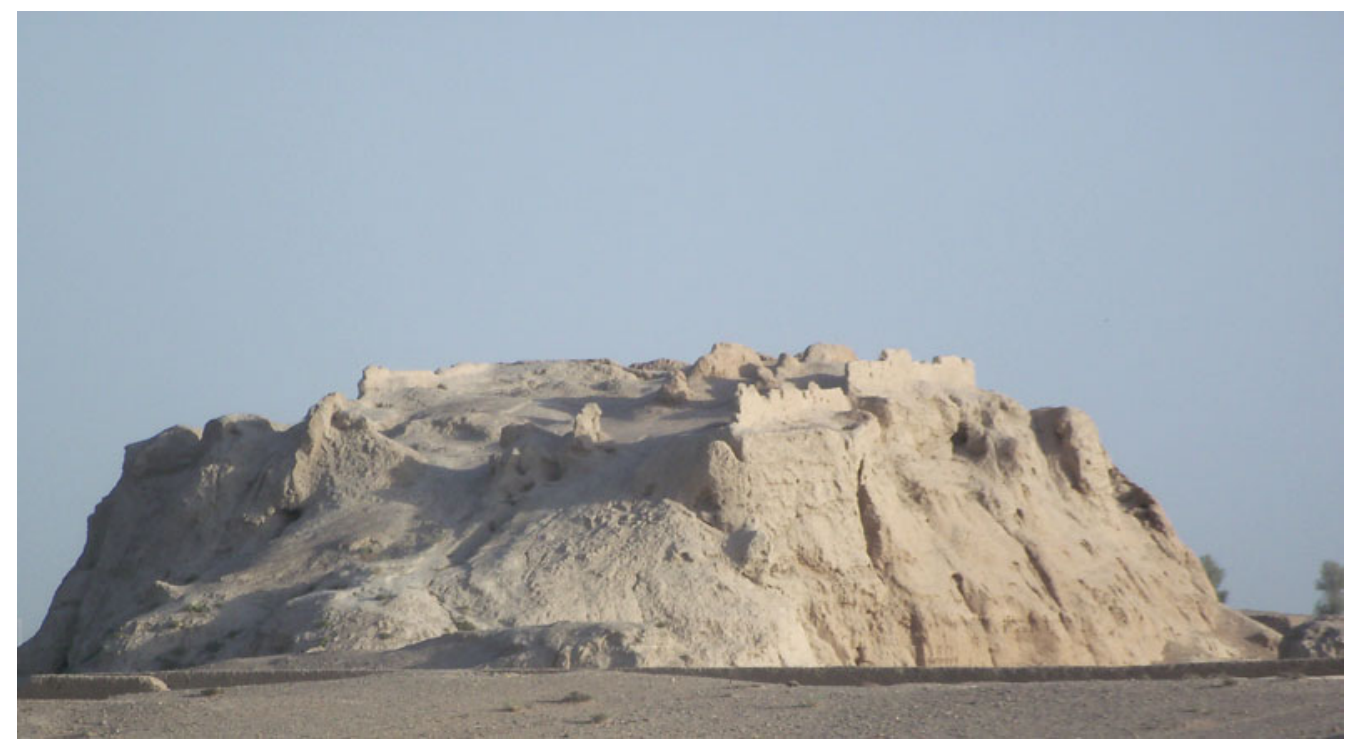

Figure 2. Archaeological site designation CHCP-12, consisting of a mound with mud-brick constructions located on and around it.

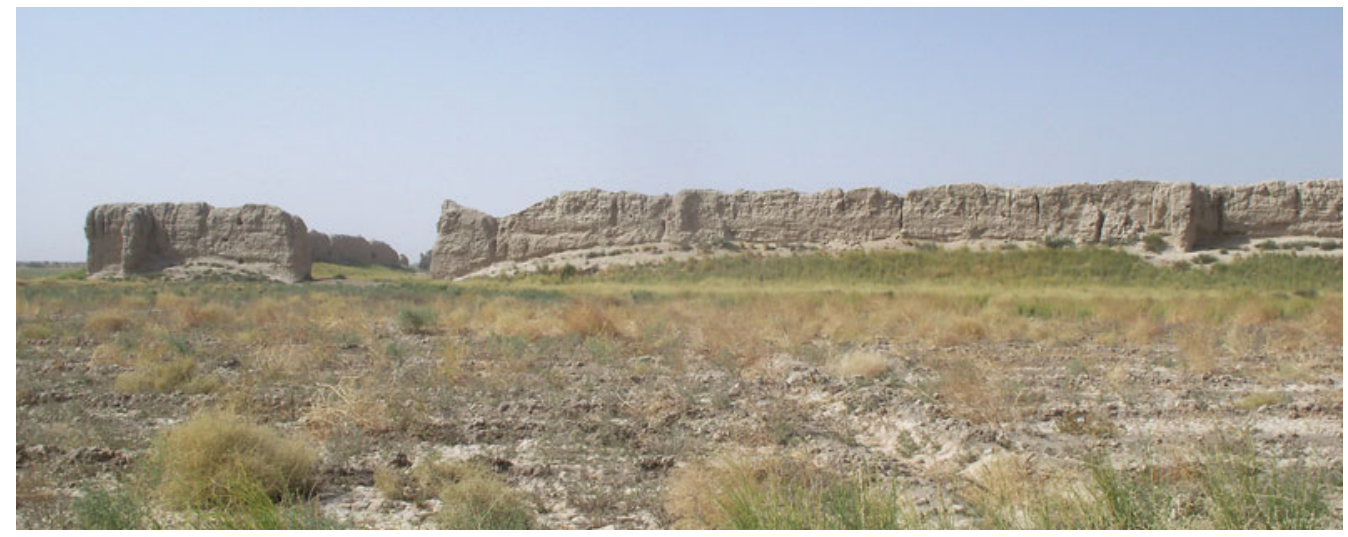

Figure 3. Enclosure (probably of a settlement) wall associated with archaeological site designation CHCP-4.

in Khan Neshin District, but only two of these sites produced diagnostic ceramic sherds.

All the sites examined in the central Helmand Valley form mounds that rise conspicuously from the uniform desert shelf (Figure 2). Atop most of these mounds are the remains of mud-brick buildings in various states of attrition. Most constructions appear to relate to the Islamic period, with the majority dating to the Middle Ages. Three mounds are surrounded by large enclosure walls (Figure 3), and, on the basis of architectural characteristics, the general layout of the structures and associated ceramics, were probably medieval fortresses. 


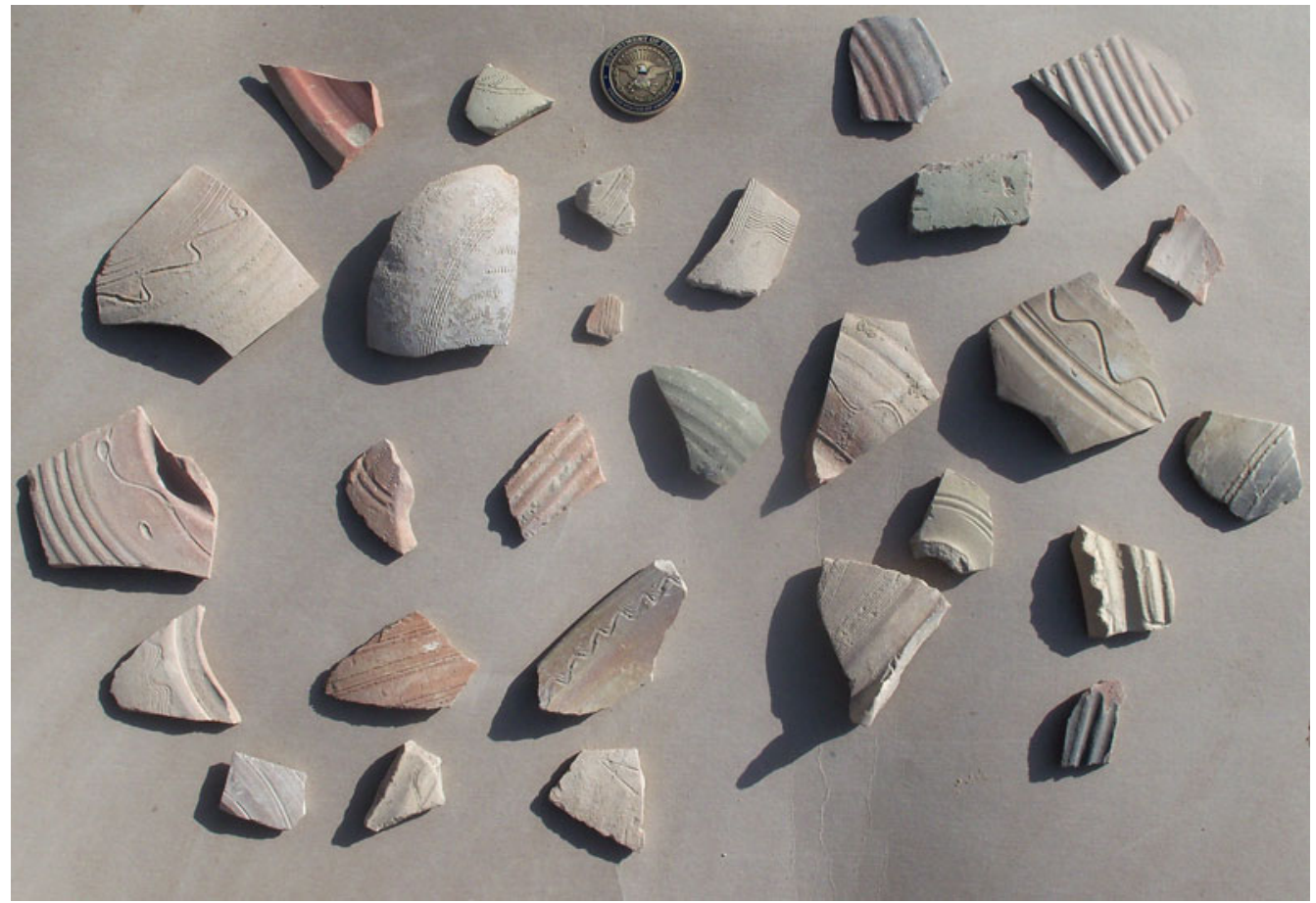

Figure 4. Ceramics, mainly with recessed (incised, ribbed) designs. Token for scale is $44.45 \mathrm{~mm}$ in diameter.

The ceramics and other materials collected imply that the sites were in use from the early Islamic period (AD 651-900)_and possibly as early as the Kushan period (50 BC-AD 300) - until recent times. The ceramics are mainly red and buff wares with a few grey ware and black ware examples. Designs tend to be recessed or in relief, rather than painted. Recessed designs were made by pressing a sharp implement or mould into the leather-hard clay before firing (Figure 4). The majority of recessed designs consist of either puncture marks or incised lines ranging from wavy striations to straight, diagonal or horizontal striations. Other, more ornate recessed designs, some in the form of leaves, were created using a mould. Zavyalov (2008: 144-45) states that leaf symbolism is most common on Kushano-Sassanian ware and that it has religious or astral significance. The designs in relief are elaborate, consisting of stand-alone as well as repeating geometric patterns, and are most probably of Ghaznavid or Ghurid date (late tenth to early thirteenth centuries AD) (Figure 5). Evidence of burnishing, slips and glazes can be found on some of the ceramics. The red-streak burnished sherds could date to Kushan times (Charles Kolb pers. comm. 2015). More definitive dating comes from the glazed sherds (Figure 6). One red-and-black-glazed sherd can be identified as 'Samarkand tomato ware' (eighth to tenth centuries AD), whereas the majority of glazed ware is bright green and yellow and can be dated to the Ghaznavid or Ghurid period; some of the blue-glazed ware sherds are probably Timurid (fourteenth to sixteenth centuries AD) (Norman Hammond pers. comm. 2016).

(C) Antiquity Publications Ltd, 2017 


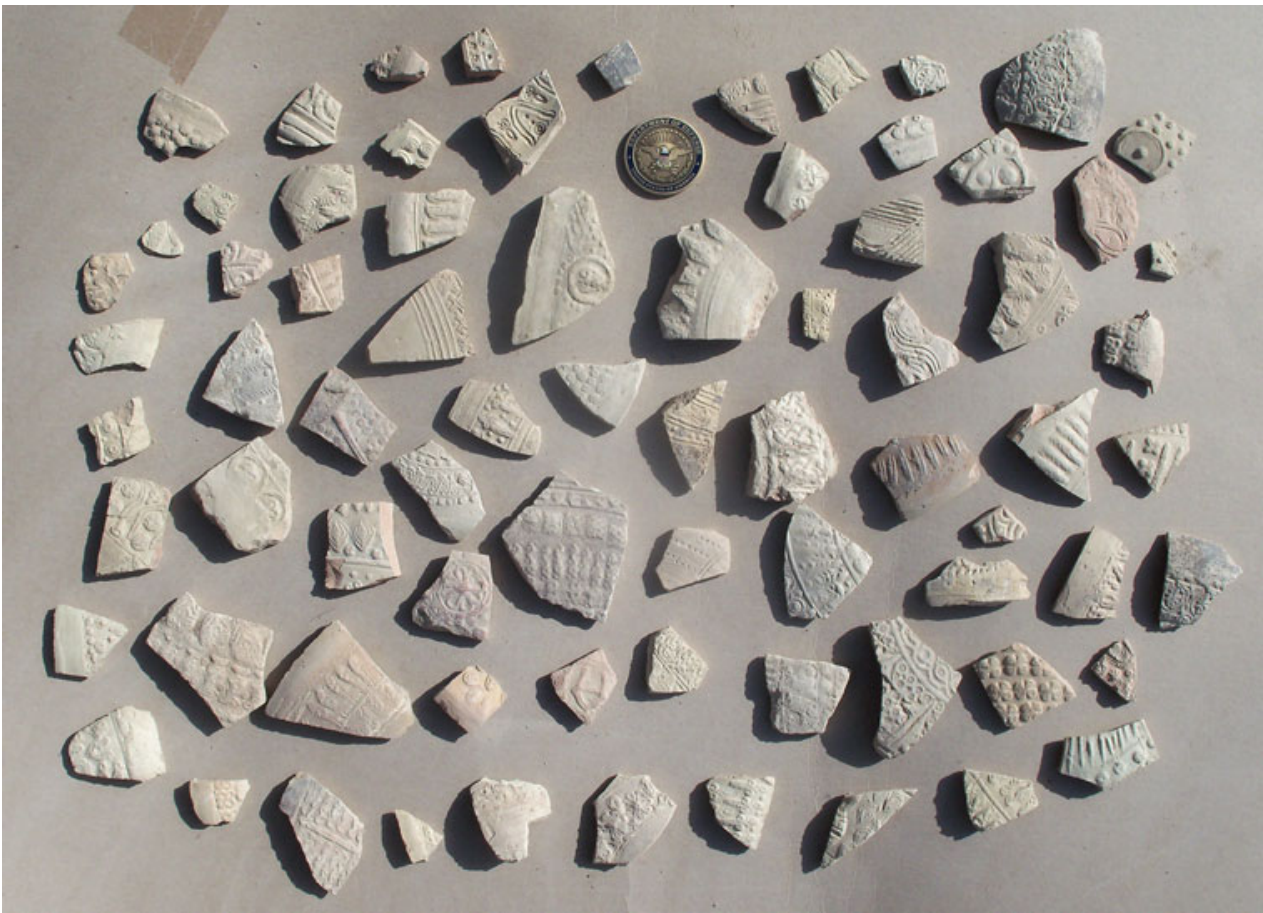

Figure 5. Ceramics in relief, mainly mould-made Ghaznavid wares. Token for scale is $44.45 \mathrm{~mm}$ in diameter.

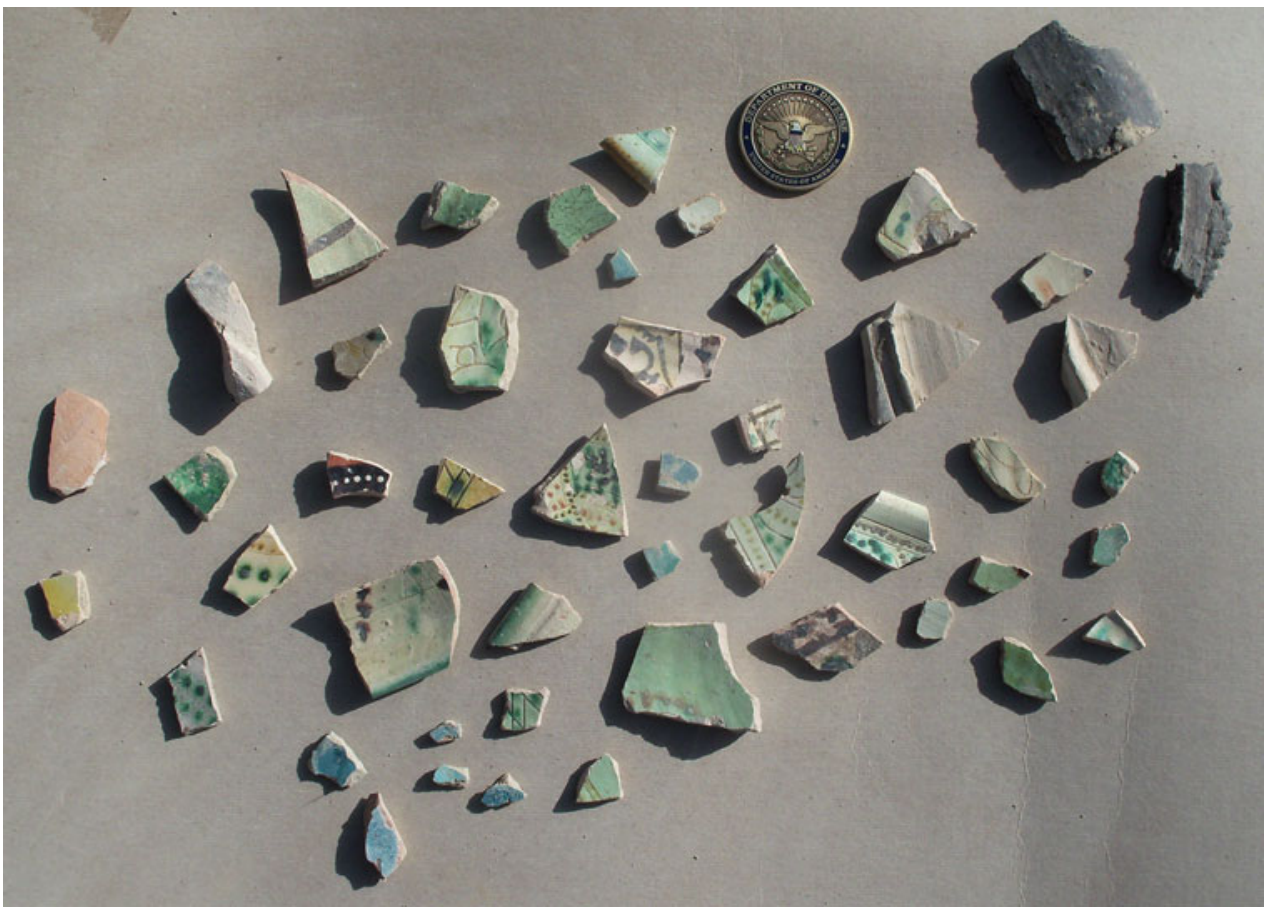

Figure 6. Glazed Islamic ceramics, including sgraffiato types. Token for scale is $44.45 \mathrm{~mm}$ in diameter.

(C) Antiquity Publications Ltd, 2017 


\section{Conclusion}

Preliminary analysis of the surface finds at the surveyed sites indicates activity predominantly of medieval date. That the sites occupy what has been characterised as a prehistorically rich area (dating to at least the Chalcolithic period), however, suggests that the prehistoric record has yet to be uncovered in the central Helmand Valley. Several of the mounds surveyed appear to be tepe, formed through the construction and reconstruction of successive mud-brick settlements over a significant period of time. The quantity of clay in the mud used to make the brick, coupled with erosion, has turned the more recent mudbrick into a thick, sun-baked sarcophagus encasing the lower, older layers. If the prehistoric record is present as might be assumed, then vertical excavations will be the only means of exposing the full array of cultural sequences at these sites.

\section{Acknowledgements}

This study would not have been undertaken if not for the support of the MoIC, the US Army and US Marine Corps Regimental Combat Teams 1 and 5. I will always be grateful to Wilem Wong, Laura Tedesco and Omar Sultan for their backing, and to Baharullah Ali for his indispensable assistance in the field. Finally, I would like to thank Norman Hammond, Charles Kolb and Jim Shaffer for their help with identifying many of the ceramics and providing invaluable insight into the region.

\section{References}

Abramiuk, M.A. \& W. Wong. 2015. Cultural heritage preservation and its role for paving the way toward peace. Small Wars Journal. Available at: http://smallwarsjournal.com/jrnl/art/culturalheritage-preservation-and-its-role-for-paving-theway-toward-peace (accessed 18 August 2017).

Allchin, F.R. \& N. Hammond (ed.). 1978. The archaeology of Afghanistan, from earliest times to the Timurid period. London: Academic.

Hammond, N. 1970. An archaeological reconnaissance in the Helmand Valley, south Afghanistan. East and West 20: 437-59.
Shaffer, J.G. 1992. The Indus Valley, Baluchistan, and Helmand Traditions: Neolithic through Bronze Age, in R.W. Ehrich (ed.) Chronologies in Old World archaeology (volume 1): 441-64. Chicago (IL): University of Chicago Press.

Tosi, M. 1968. Excavations at Shahr-i Sokhta, a Chalcolithic settlement in the Iranian Sīstān. East and West 18: 9-66.

Zavyalov, V. 2008. Kushanshakhr pri Sasanidakh: po materialam raskopok gorodishcha Zartepa. St Petersburg: St Petersburg State University Faculty of Philology and Arts. 